\title{
AGGREGATE STABILITY BY THE "HIGH ENERGY MOISTURE CHARACTERISTIC" METHOD IN AN OXISOL UNDER DIFFERENTIATED MANAGEMENT ${ }^{(1)}$
}

\author{
Érika Andressa da Silva ${ }^{(2)}$, Geraldo César de Oliveira ${ }^{(3)}$, Bruno Montoani Silva ${ }^{(4)}$, Carla \\ Eloize Carducci $^{(5)}$, Junior Cesar Avanzi ${ }^{(6)}$ \& Milson Evaldo Serafim ${ }^{(7)}$
}

\begin{abstract}
SUMMARY
Studies testing the High Energy Moisture Characteristic (HEMC) technique in tropical soils are still incipient. By this method, the effects of different management systems can be evaluated. This study investigated the aggregation state of an Oxisol under coffee with Brachiaria between crop rows and surfaceapplied gypsum rates using HEMC. Soil in an experimental area in the Upper São Francisco region, Minas Gerais, was studied at depths of 0.05 and $0.20 \mathrm{~m}$ in coffee rows. The treatments consisted of 0,7 , and $28 \mathrm{Mg} \mathrm{ha}^{-1}$ of agricultural gypsum rates distributed on the soil surface of the coffee rows, between which Brachiaria was grown and periodically cut, and compared with a treatment without Brachiaria between coffee rows and no gypsum application. To determine the aggregation state using the HEMC method, soil aggregates were placed in a Büchner funnel $(500 \mathrm{~mL})$ and wetted using a peristaltic pump with a volumetric syringe. The wetting was applied increasingly at two pre-set speeds: slow $\left(2 \mathrm{~mm} \mathrm{~h}^{-1}\right)$ and fast $\left(100 \mathrm{~mm} \mathrm{~h}^{-1}\right)$. Once saturated, the aggregates were exposed to a gradually increasing tension by the displacement of a water column (varying from 0 to $30 \mathrm{~cm}$ ) to obtain the moisture retention curve $[M=f(\Psi)]$, underlying the calculation of the stability parameters: modal suction, volume of drainable pores (VDP), stability index (slow and fast), VDP ratio, and stability ratio. The HEMC method conferred sensitivity in quantifying the aggregate stability parameters, and independent of whether gypsum was used, the soil managed with Brachiaria between the coffee rows,
\end{abstract}

(1) Received for publication on October 8, 2013 and approved on July 2, 2014.

(2) Master student in Soil Science at Department of Soil Science, Federal University of Lavras - DCS-UFLA. Caixa Postal 3037. CEP 37200-000 Lavras (MG), Brazil. CNPq fellowship. E-mail: andressa_erika@hotmail.com

(3) Associate Professor, DCS-UFLA. CNPq fellowship. E-mail: geraldooliveira@dcs.ufla.br

(4) Substitute Professor and Doctoral Student in Soil Science, DCS-UFLA, CNPq fellowship. E-mail: brunom@dcs.ufla.br

(5) Auxiliary Professor, University of Santa Catarina. Caixa Postal 101. CEP 89520-000 Curitibanos (SC), Brazil. Email:ec.carducci@ufsc.br

(6) Professor, College of Animal Science and Food Engineering, University of São Paulo - FZEA/USP. Av. Duque de Caxias Norte, 225. CEP 13635-900 Pirassununga (SP), Brazil. E-mail: javanzi@gmail.com

(7) Professor, Federal Institute of Education, Science and Technology of Mato Grosso. Av. dos Ramires, s/n, Distrito Industrial. CEP 78.200-000 Cáceres (MT), Brazil. E-mail: milson.serafim@cas.ifmt.edu.br 
with regular cuts discharged in the crop row direction, exhibited a decreased susceptibility to disaggregation.

Index terms: aggregation, coffee production, management systems, method.

\title{
RESUMO: ESTABILIDADE DE AGREGADOS PELO MÉTODO HIGH ENERGY MOISTURE CHARACTERISTIC, EM LATOSSOLO SOB MANEJO DIFERENCIADO
}

\begin{abstract}
Estudos com a técnica High Energy Moisture Characteristic (HEMC) ainda são incipientes em solos tropicais. Por considerar a HEMC como um potencial de avaliação dos impactos decorrentes da adoção de sistemas de manejo do solo, este trabalho objetivou determinar, por meio desse método, o estado de agregação de um Latossolo que recebeu diferentes doses de gesso na superfície e foi manejado com braquiária nas entrelinhas de cafeeiro. Foram estudadas as profundidades de 0,05e 0,20 $\mathrm{m}$, na linha do cafeeiro, em uma área experimental localizada na região do Alto São Francisco, MG. Os tratamentos corresponderam às doses de 0, 7, e $28 \mathrm{Mg} \mathrm{ha}^{-1}$ de gesso agrícola distribuído na superfície do solo e na linha do cafeeiro, com presença e corte periódico de braquiária na entrelinha, utilizando como testemunha um tratamento sem braquiária na entrelinha do cafeeiro e sem gesso na linha. Para determinar o estado de agregação do solo empregando HEMC, os agregados foram colocados em funil de Büchner $(500 \mathrm{~mL})$ e umedecidos, utilizando-se uma bomba peristáltica com seringa volumétrica. $O$ umedecimento se deu de maneira ascendente em duas velocidades preestabelecidas: lenta $\left(2 \mathrm{~mm} \mathrm{~h}^{-1}\right)$ e rápida $\left(100 \mathrm{~mm} \mathrm{~h}^{-1}\right)$. Depois de saturados, os agregados foram submetidos ao aumento gradual da tensão a partir do deslocamento de uma coluna de água (variando de 0 a $30 \mathrm{~cm}$ ) para obtenção da curva de retenção de água nos pontos de baixa tensão $(U=f(\Psi))$, que serviu de base para os cálculos dos parâmetros de estabilidade: sucção modal, volume drenável de poros (VDP), índices de estabilidade (lento e rápido), razão VDPe razão de estabilidade. O método High Energy Moisture Characteristic apresentou sensibilidade para a quantificação dos parâmetros de estabilidade de agregados e, independente das doses de gesso utilizadas, o solo manejado com braquiária na entrelinha do cafeeiro, com cortes periódicos direcionados para a linha da cultura, apresentou menor susceptibilidade à desagregação.
\end{abstract}

Termos de indexação: agregação, cafeicultura, sistemas de manejo, método.

\section{INTRODUCTION}

Brazilian coffee stands out from competitors because of recent increases in productivity and quality. The use of good soil management practices, aside from addressing concerns related to product quality, is a requirement for coffee certification (BSCA, 2005; Minas, 2013). Management systems that aim to increase production and product quality and are associated with soil structural quality improvement and environmental sustainability have been widely discussed. In Brazil, a management system used in the south and southwest of Minas Gerais has attracted the attention of producers, agronomists, and researchers. The system involves the application of high gypsum rates to the soil surface, and grass planted between the coffee rows. A notable feature of the system is the preparation of the planting furrow by mixing and soil acidity and fertility correction to $60 \mathrm{~cm}$ depth (Serafim et al., 2011; Serafim et al., 2013).

Gypsum application to the soil surface and the use of Brachiaria as cover crop between coffee rows are more controversial practices, because although the gypsum is an important calcium and sulfur source for plants, high rates may result in the "leaching" of bases from the soil profile, because the sulfate ion resulting from cleavage has high soil mobility (Serafim et al., 2012) and can carry away exchangeable bases. Positive effects of this base "leaching" include the potential for immobilizing toxic $\mathrm{Al}$ and promoting nutrient redistribution in depth, which favors root growth and allows the exploration of a larger soil volume that results in greater access to water in the deep soil layers (Serafim et al., 2011; Silva et al., 2012; Serafim et al., 2013).

Growing grass between coffee rows, despite the competition for water and nutrients (Fialho et al., 2012), can contribute to a high input of organic matter, with favorable effects on soil aggregation (Lima et al., 2012; Silva et al., 2013). This practice can also reduce problems arising from soil compaction (Magalhães et al., 2009; Severiano et al., 2010; Lima et al., 2012), due to biopore formation. Biopores are alternative routes for root growth and promote considerable increases in water, gas, and nutrient diffusion in the 
soil (Kondo et al., 2012). Suggestions for Brachiaria management between rows of perennial crops are found in the literature (Fialho et al., 2011; Fialho et al., 2012).

Despite the positive effects of soil aggregation being related to the success of many soil management systems (Kondo et al., 2012; Silva et al., 2013) and the environmental quality of agroecosystems (Casalinho et al., 2007), there is no consensus in the literature regarding aggregate measurement method and stability. Therefore, the application of traditional methods, such as wet and dry sieving (Yoder, 1936), simulated raindrop impact resistance, and ultrasonic energy (Ribeiro et al., 2009), is limited (Sá et al., 2000).

In order to circumvent the limitations of traditional techniques, a method called High Energy Moisture Characteristic (HEMC) (Childs, 1940) was proposed, which has been improved in recent decades (Pierson \& Mulla, 1989; Levy \& Mamedov, 2002). However, being relatively untested in tropical soils, its divulgation in Brazil has occurred only recently (Avanzi et al., 2011). This technique involves a greater control of aggregate wetting, to improve the management of the hydration energy and effects of air trapped within the aggregates, as these are the parameters responsible for slaking. Therefore, it is a very sensitive technique (Avanzi et al., 2011) to detect even small changes in pore-size distribution as caused by soil use, allowing a comparison of soil management systems.

As studies using the HEMC technique are still incipient in tropical soils, this study aimed to test it in evaluations of aggregate stability and interaggregate porosity in a clayey Oxisol under coffee and different gypsum rates applied to the soil surface, and Brachiaria growing between coffee rows, compared to the absence of use of these two practices.

\section{MATERIAL AND METHODS}

The experimental area is located in São Roque de Minas, a physiographic region of the Upper São Francisco $\left(20^{\circ} 152 \mathrm{~S}\right.$ and $46^{\circ} 222 \mathrm{~W}, 900 \mathrm{~m}$ above sea level), in the State of Minas Gerais, southwestern Brazil. The soil in this study was classified according to Embrapa (2006) as a gibbsitic-oxidic Oxisol, with a very clayey texture (Latossolo Vermelho distrófico in the Brazilian classification) (Table 1), and was used to cultivate the 'Yellow Catuaí' variety of coffee (Coffea arabica L.).

The treatments consisted of two management systems that consisted of furrowing to a depth of $60 \mathrm{~cm}$, with the incorporation of lime, gypsum, and fertilizer, following the recommendations of the State of Minas Gerais (CFSEMG, 1999), with and without the use of Brachiaria between rows, and the application of different gypsum rates to the crop rows (Table 2). In the differentiated management system, Brachiaria is sown before coffee planting, as described by Serafim et al. (2011).

The chemical characteristics of the Oxisol under study prior to the experiment are presented in table 3 . The samples were collected at positions that corresponded to lines with the presence or absence of Brachiaria, which corresponded to treatments with differentiated management systems (G-0, G-7, and G28) and conventional management systems (CV-0), respectively.

Before crop establishment in November 2008, the soil was tilled between July and August (one plowing and two harrowings). In addition to these operations, $8 \mathrm{Mg} \mathrm{ha}{ }^{-1}$ of dolomitic limestone (with $17 \% \mathrm{Mg}$ ), divided into two applications, and $2 \mathrm{Mg} \mathrm{ha}^{-1}$ of agricultural gypsum were applied. The material was incorporated to a depth of $20 \mathrm{~cm}$. After this preparation, Brachiaria decumbens was planted. For coffee planting, a subsoiler tool coupled to a rotary hoe was used, to open-plant furrows $(60 \mathrm{~cm}$ deep, $50 \mathrm{~cm}$ wide), in which the soil was homogeneously mixed with lime and fertilizer to a depth of $60 \mathrm{~cm}$. In the planting furrow, $2 \mathrm{Mg} \mathrm{ha}^{-1}$ lime and $880 \mathrm{~kg}$ of the formula 08-44-00 ( $\mathrm{P}$ as monoammonium phosphate, $1 \% \mathrm{ZnO}$, and $0.5 \% \mathrm{~B}$ in ulexite form) were added to the 0.20-0.60 m layer for correction. In the planting rows, fertilization with $20 \mathrm{~g}$ of ammonium nitrate per plant was applied four times in the first year; in the whole area, coffee straw coverage $\left(7 \mathrm{~L} \mathrm{~m}^{-1}\right)$ and nitrogen fertilizer (250 kg ammonium nitrate) were applied.

Three months after planting the coffee seedlings, additional agricultural gypsum was distributed on the soil surface along the crop row $\left(1.75 \mathrm{~kg} \mathrm{~m}^{-1}\right.$ in treatment G-7 and $7 \mathrm{~kg} \mathrm{~m}^{-1}$ in G-28), followed by mounding of soil material mixed with Brachiaria debris at the plant base, using a tractor blade. Brachiaria was maintained between the rows as cover crop as part of the management system. During the

Table 1. Chemical (sulfuric acid digestion) and physical (soil fractions) characteristics of the "Ap" and "Bw" horizons of an Oxisol

\begin{tabular}{|c|c|c|c|c|c|c|c|c|c|}
\hline Horizon & Clay & Silt & Sand & $\mathrm{SiO}_{2}$ & $\mathrm{Al}_{2} \mathrm{O}_{3}$ & $\mathrm{Fe}_{2} \mathrm{O}_{3}$ & $\mathbf{P}_{2} \mathbf{O}_{5}$ & $\mathbf{K i}$ & $\mathbf{K r}$ \\
\hline Ap & 763 & 198 & 39 & 102 & 355 & 157 & 1.32 & 0.49 & 0.38 \\
\hline $\mathrm{Bw}$ & 819 & 148 & 33 & 105 & 392 & 169 & 0.98 & 0.46 & 0.36 \\
\hline
\end{tabular}


Table 2. Experimental treatments of coffee under different management systems

\begin{tabular}{cccc}
\hline Treatment & System & Cover crop & Topdressed gypsum \\
\hline & & & $\mathrm{Mg} \mathrm{ha}^{-1}$ \\
CV-0 & Conventional & Absent & 0 \\
G-0 & Differentiated & Brachiaria & 0 \\
G-7 & Differentiated & Brachiaria & 7 \\
G-28 & Differentiated & Brachiaria & 28 \\
\hline
\end{tabular}

Table 3. Chemical characteristics of an Oxisol after soil tillage and before coffee planting

\begin{tabular}{|c|c|c|c|c|c|c|c|}
\hline Depth & $\mathrm{pH}\left(\mathrm{H}_{2} \mathrm{O}\right)$ & $\mathrm{Al}^{3+}$ & $\mathbf{C a}^{2+}$ & $\mathrm{Mg}^{2+}$ & $\mathbf{K}^{+}$ & $\mathbf{S}$ & $\operatorname{SOM}^{(1)}$ \\
\hline \multirow[t]{2}{*}{$\mathrm{m}$} & & 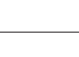 & $\mathrm{nol}_{\mathrm{c}} \mathrm{dn}$ & 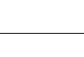 & - & & dag $\mathrm{kg}^{-1}$ \\
\hline & \multicolumn{7}{|c|}{ Presence of Brachiaria } \\
\hline $0.00-0.20$ & 4.9 & 0.2 & 1.4 & 0.6 & 29.3 & 54 & 3.3 \\
\hline $0.20-0.40$ & 5.0 & 0.2 & 0.9 & 0.3 & 20.9 & 47 & 3.1 \\
\hline $0.40-0.60$ & 5.1 & 0.2 & 0.8 & 0.3 & 18.4 & 22 & 2.9 \\
\hline \multirow[t]{2}{*}{$0.60-0.80$} & 5.0 & 0.2 & 1.0 & 0.4 & 22.9 & 37 & 3.1 \\
\hline & \multicolumn{7}{|c|}{ Absence of Brachiaria } \\
\hline $0.00-0.20$ & 5.1 & 0.1 & 1.9 & 0.8 & 26.8 & 32 & 3.4 \\
\hline $0.20-0.40$ & 5.0 & 0.2 & 1.1 & 0.5 & 19.3 & 39 & 3.1 \\
\hline $0.40-0.60$ & 5.1 & 0.2 & 1.2 & 0.5 & 19.7 & 43 & 3.0 \\
\hline $0.60-0.80$ & 5.1 & 0.1 & 0.5 & 0.2 & 11.5 & 13 & 2.4 \\
\hline
\end{tabular}

(1) SOM: soil organic matter.

five years of cultivation, Brachiaria decumbens was periodically cut with a brushcutter that thrusted the cut material into the plant rows (Serafim et al, 2011; Silva et al., 2013). In the second year of cultivation, the grass received $600 \mathrm{~kg}$ of $\mathrm{K}_{2} \mathrm{O}$ fertilizer, distributed over four applications per year.

Additional gypsum was applied as topdressing between February and March 2009, at the respective treatment rates, at a distance of $0.5 \mathrm{~m}$ from the coffee plant rows. After soil sampling, the gypsum was covered with approximately $0.15 \mathrm{~m}$ of soil (Serafim et al., 2011, Silva et al., 2012; Silva et al., 2013). The soil was sampled in the plant row at a depth of $0.05 \mathrm{~m}$ (from the mounds in the differentiated management systems) and $0.20 \mathrm{~m}$ (but below the gypsum layer in the differentiated management systems), with three replications (trench) per treatment (CV-0, G-0, G-7, and G-28), totaling 24 samples. At sampling, the coffee trees were 2.5 years old.

To assess soil aggregate stability by the HEMC technique, the method described by Pierson \& Mulla (1989) was used. By this method, the wetting process of the aggregates is accurately controlled, and the energy of hydration and entrapped air are the only forces responsible for aggregation breakdown. An index of aggregate stability is obtained by quantifying differences in the moisture characteristic curves after fast and slow wetting (Mamedov et al., 2007). The equipment, adapted from Avanzi et al. (2011), was developed in the Physics and Soil Conservation Laboratory (Figure 1).

Instructions for performing the HEMC technique are given in detail by Levy \& Mamedov (2002), and an overview of the method follows. For the test, $15 \mathrm{~g}$ of dry aggregates (diameter 0.5-1.0 $\mathrm{mm}$ ) were placed in funnels (previously saturated). In the funnels, thin layers of aggregates were spread on the porous material (Levy \& Mamedov, 2002). The bottom of the funnel was connected by tubing to a peristaltic pump (Figure 1), which was then used to wet the aggregates in the funnel, either rapidly $\left(100 \mathrm{~mm} \mathrm{~h}^{-1}\right)$, or slowly $\left(2 \mathrm{~mm} \mathrm{~h}^{-1}\right)$. At the end of the wetting, the aggregates were covered by standing water to ensure saturation. A tension of $0.1 \mathrm{kPa}$ was then applied to the samples, and the moisture values obtained from each tension were used to generate soil moisture curves for each wetting rate (Figure $2 \mathrm{a}$ ). The water volume that drained from the aggregates at each matric potential was recorded after a 2 min equilibrium period, and the corresponding water content of the aggregates was calculated. A moisture characteristic curve $(M=f(\Psi)$ was obtained, with a matric potential $(\Psi)$ that ranged from 0 to $-3 \mathrm{kPa}$, using the displacement of a water column $(0.0-0.30 \mathrm{~m})$. To accurately calculate the volume of drainable pores (VDP) and modal suction (MS), moisture characteristic curves were fitted using a modified van Genuchten model, proposed by Pierson \& Mulla (1989), according to equation 1: 


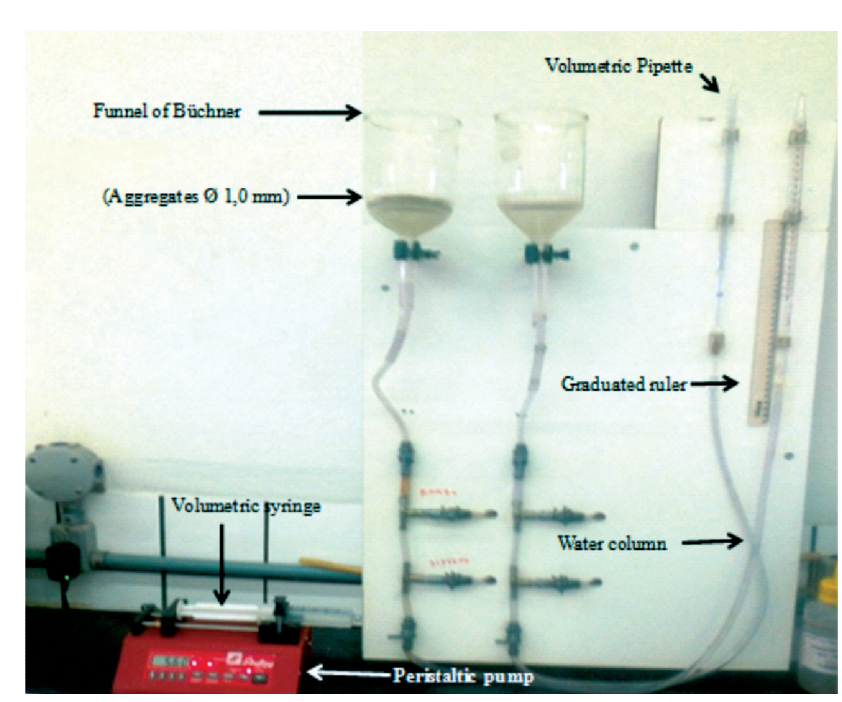

Figure 1. Equipment designed to evaluate the stability of aggregates by the HEMC method, adapted from Avanzi et al. (2011).

$$
U=U r+(U s-U r)\left[1+(a \Psi)^{n}\right]^{(1 / n-1)}+A \Psi^{2}+B \Psi+C
$$

where $U s$ and $U r$ are the saturated and residual gravimetric water contents, respectively; $\alpha$ and $n$ are empirical parameters for the model and are determined from the inflection of the characteristic moisture curve plotted for the observed data; and A, B, and C are the quadratic terms suggested by Pierson \& Mulla (1989) to best fit the curve.

The water specific capacity curve (du/d $\Psi)$, by which the MS values were obtained, was calculated by differentiation, according to equation 2 :

$$
\begin{aligned}
& (d u / d \psi)=(U s-U r)\left[1+(\alpha \psi)^{n}\right]^{(1 / n-1)} \\
& \left(\frac{1}{n}-1\right)(\alpha \psi)^{n}\left(\frac{n}{\left\{\psi\left[1+\alpha \psi^{n}\right]\right\}}\right)+2 A \psi+B
\end{aligned}
$$

The drainable pore volume (DPV) was calculated by subtracting the pore contraction conditions $(2 \mathrm{~A} \Psi+\mathrm{B})$ from equation 2 , and analytically integrating the equation. The VDP corresponds to the area under the moisture characteristic curve (Figure $2 \mathrm{~b}$ ) and above the solid line. The MS, in turn, is the value of $\Psi$ at the maximum point of the moisture characteristic curve (Figure 2b).

The aggregate stability index (SI) for each wetting speed was calculated according to equation 3, proposed by Collis-George \& Figueroa (1984).

$$
S I=V D P / M S
$$

The aggregate stability, represented by the stability ratio (SR), was calculated according to equation 4 , as proposed by Pierson \& Mulla (1989), and used in the comparison of the resistance to aggregate slaking on a scale from 0 to 1.
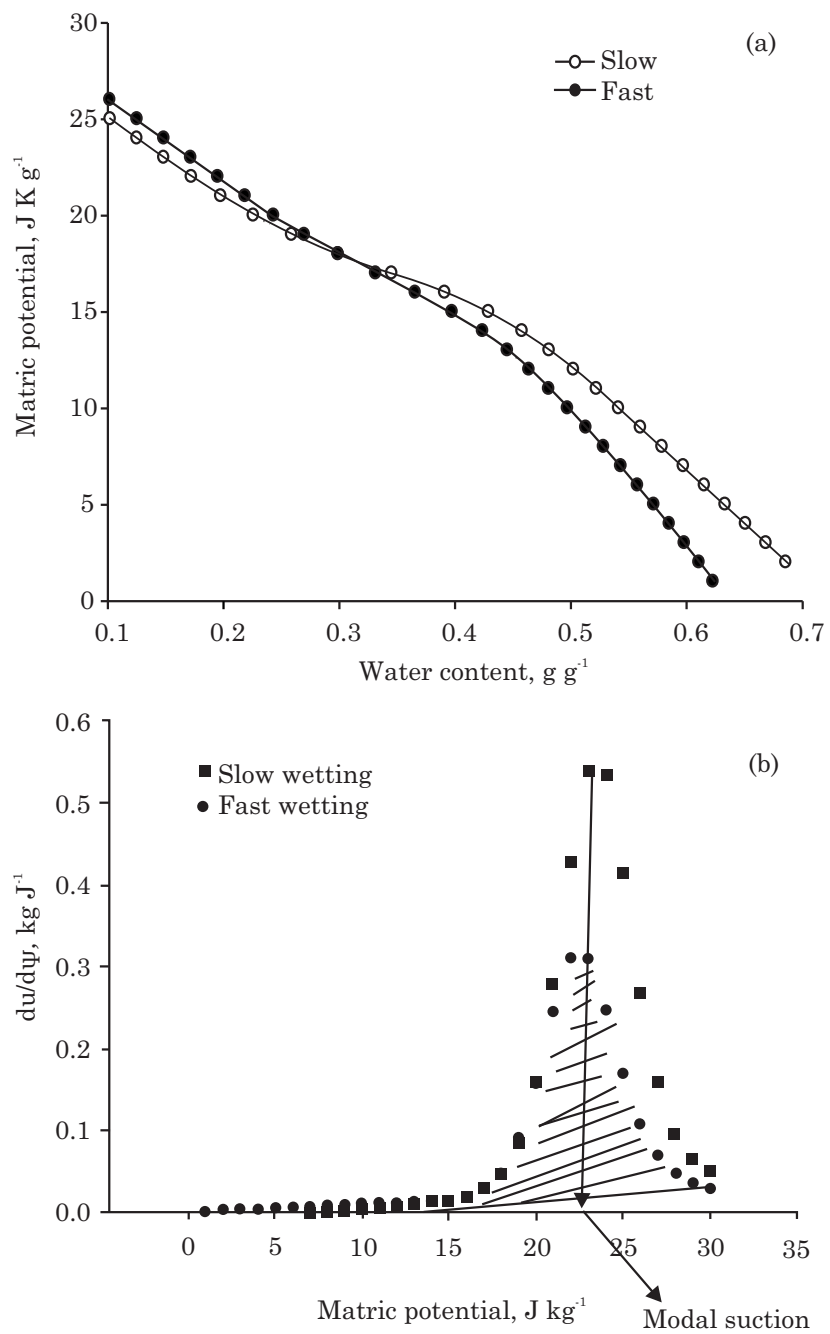

Figure 2. Schematic representation of the water drain curve (a) and the moisture characteristic curve for fast and slow wetting (b).

$$
S R=S I_{\text {fast }} / S I_{\text {slow }}
$$

In order to study water retention using the aggregate model proposed by van Genuchten (1980), with restriction $\mathrm{m}=1-1 / \mathrm{n}$ (Mualem, 1976), the experimental data were adjusted according to equation (5), using software SWRC (Seki, 2007).

$$
M=(\text { Msat }- \text { Mres })\left[1+(\alpha \Psi)^{n}\right]^{1-1 / n}+\text { Mres }
$$

where $M$ is the water content of the soil $\left(\mathrm{g}^{-1}\right)$; $\Psi$ is the soil water potential $(\mathrm{kPa}) ;$ Msat the water content of the saturated sample ( $\left.\mathrm{g} \mathrm{g}^{-1}\right)$; Mres the water content $\left(\mathrm{g} \mathrm{g}^{-1}\right)$ in the matric potential of $-3 \mathrm{kPa}$; and $n$ and $\alpha$ are empirical parameters of the model fit.

For pore quantification by diameter, we used the mathematical expression:

$$
D=4 s \operatorname{Cos} \theta / \Psi m
$$

where $D$ is the pore diameter $(\mathrm{mm}) ; s$ the water surface tension $\left(73.43 \mathrm{kPa} \mathrm{mm}\right.$ at $\left.20^{\circ} \mathrm{C}\right) ; \theta$ the contact angle between the meniscus and the wall of the 
capillary tube (assumed to be 0); and $\Psi m$ the matric potential in the soil $(\mathrm{kPa})$ for each given potential.

The treatments were arranged in a factorial, completely randomized block design, with the following study factors: management and wetting rate of the aggregates, with four levels of management and two levels of wetting rate, with three replications ( $\mathrm{n}=48,24$ for each depth). The data were tested for normality by the Shapiro-Wilk test and the criteria were fulfilled. The data were subjected to analysis of variance (ANOVA), and the means compared by the Scott-Knott and Fisher's Least Significant Difference (LSD) test at $5 \%$, using SISVAR software (Ferreira, 2011).

\section{RESULTS AND DISCUSSION}

The results for aggregate stability, determined by the HEMC technique and expressed as modal suction (MS), volume of drainable pores (VDP), slow and fast stability index (SI) and VDP and stability ratio (SR) values, are presented in table 4 .

At a soil depth of $0.05 \mathrm{~m}$, significant differences were observed between the managements for fast VDP, particularly G-28, which had significantly higher values than CV-0 (Table 4). This indicates that management with Brachiaria covering the interrows and high gypsum applications promotes the formation of more resistant aggregates. If the soil aggregates under management had increased stability under a fast wetting rate, then presumably they would also be resistant to heavy rain, and tend to be less susceptible to slaking. Moreover, management systems that promote the formation of aggregates that disintegrate quickly under the wetting rate tend to release fine sand and silt (Mamedov et al., 2007), particles that are related to the clogging of pores, which decreases soil permeability (Lado et al., 2004). Potentially useful practical information that results from the above observation is the ability to predict the formation of soil surface sealing using the HEMC technique.

In spite of the non-existence of significant differences between the systems in the SR at a depth of $0.05 \mathrm{~m}$, treatments G-7 and G-28 exhibited values of above 0.5 (Table 4 ), which has been associated with adequate aggregate stability (Levy \& Miller, 1997). It should be noted that stable aggregates exhibit tightly bound soil fractions that are rarely broken, mainly due to the presence of organic carbon as cementing agent, and can confer good permeability and water infiltration (Lado et al., 2004; Costa Júnior et al., 2012).

At a depth of $0.20 \mathrm{~m}$, there was a significant difference among managements in SR (Table 4). In aggregate stability analyses by wet sieving (Yoder, 1936), at the same study site and under the same management systems, Silva et al. (2013) also found positive effects and better results under management using gypsum and Brachiaria than under conventional management (CV-0).

Organic matter and clays, when combined with the appropriate cations, are primarily responsible for the formation of aggregates, acting as cementing agents (Six et al., 2004). In the case of G-7 and G-28, there was a continuous source of exchangeable $\mathrm{Ca}$ and organic matter (OM), which favored better soil aggregation. In these treatments, OM was derived

Table 4. Indices of the aggregate stability of an Oxisol subjected to different managements under coffee, obtained by the HEMC technique

\begin{tabular}{|c|c|c|c|c|c|c|c|c|c|}
\hline \multirow{2}{*}{ Management } & \multicolumn{2}{|c|}{ Modal suction } & \multicolumn{2}{|c|}{ Volume of drainage pore } & \multicolumn{2}{|c|}{ Stability index } & \multirow{2}{*}{$\begin{array}{c}\text { VDP ratio } \\
\text { Mean }\end{array}$} & \multicolumn{2}{|c|}{ SR } \\
\hline & Fstns & Slwns & Fst* & Slwns & Fstns & Slw*** & & Mean* & $\begin{array}{c}\text { Standard } \\
\text { error }\end{array}$ \\
\hline & $-\mathrm{c}$ & & g g & $\longrightarrow$ & g g. & $\mathrm{m}^{-1}$ & & & \\
\hline CV-O & $23.1 \mathrm{a}$ & $24.0 \mathrm{a}$ & $0.164 \mathrm{~b}$ & $0.358 \mathrm{a}$ & $0.007 \mathrm{a}$ & $0.015 \mathrm{~b}$ & $0.458 \mathrm{a}$ & $0.466 \mathrm{a}$ & 0.118 \\
\hline G-0 & $24.9 \mathrm{a}$ & $18.1 \mathrm{a}$ & $0.245 \mathrm{ba}$ & $0.371 \mathrm{a}$ & $0.009 \mathrm{a}$ & $0.02 \mathrm{ab}$ & $0.660 \mathrm{a}$ & $0.450 \mathrm{a}$ & 0.099 \\
\hline G-7 & $14.2 \mathrm{a}$ & $9.9 \mathrm{a}$ & $0.369 \mathrm{ba}$ & $0.484 \mathrm{a}$ & $0.026 \mathrm{a}$ & $0.048 \mathrm{a}$ & $0.762 \mathrm{a}$ & $0.541 \mathrm{a}$ & 0.040 \\
\hline $\mathrm{G}-28$ & $17.9 \mathrm{a}$ & $10.0 \mathrm{a}$ & $0.443 \mathrm{a}$ & $0.498 \mathrm{a}$ & $0.025 \mathrm{a}$ & $0.050 \mathrm{a}$ & $0.889 \mathrm{a}$ & $0.500 \mathrm{a}$ & 0.153 \\
\hline & & & & & $0.20 \mathrm{~m}$ & & & & \\
\hline $\mathrm{CV}-0$ & $24.6 \mathrm{a}$ & $24.0 \mathrm{a}$ & $0.115 \mathrm{a}$ & $0.358 \mathrm{a}$ & $0.005 \mathrm{a}$ & $0.015 \mathrm{~b}$ & $0.321 \mathrm{a}$ & $0.330 \mathrm{~b}$ & 0.006 \\
\hline G-0 & $27.4 \mathrm{a}$ & $12.9 \mathrm{a}$ & $0.306 \mathrm{a}$ & $0.386 \mathrm{a}$ & $0.011 \mathrm{a}$ & $0.029 \mathrm{a}$ & $0.792 \mathrm{a}$ & $0.379 \mathrm{a}$ & 0.061 \\
\hline G-7 & $25.0 \mathrm{a}$ & $17.0 \mathrm{a}$ & $0.320 \mathrm{a}$ & $0.488 \mathrm{a}$ & $0.012 \mathrm{a}$ & $0.028 \mathrm{a}$ & $0.655 \mathrm{a}$ & $0.428 \mathrm{a}$ & 0.015 \\
\hline$G-28$ & $24.6 \mathrm{a}$ & $27.7 \mathrm{a}$ & $0.287 \mathrm{a}$ & $0.540 \mathrm{a}$ & $0.011 \mathrm{a}$ & $0.019 \mathrm{a}$ & $0.531 \mathrm{a}$ & $0.578 \mathrm{a}$ & 0.085 \\
\hline
\end{tabular}

Fst: fast wetting; Slw: slow wetting; ns: not significant; *: significant $\mathrm{p}<0.05 ; * * *$ : significant $\mathrm{p}<0.001$. Means followed by the same letter in the column (within the same soil depth) did not differ according to Fisher's Least Significant Difference (LSD) test $(\mathrm{p}<0.05)$. 
from Brachiaria management in the crop interrows, and $\mathrm{Ca}^{2+}$ was supplied by gypsum that was applied on the surface, and covered by a layer called "mound" (Brachiaria residue and soil). Therefore, at a depth of $0.20 \mathrm{~m}$, there was a reservoir of gypsum, which, due to dry conditions in the Upper São Francisco region, underwent slow dissolution and gradually released $\mathrm{Ca}^{2+}$ to the soil at appropriate levels $\left(27 \mathrm{mmol}_{\mathrm{c}} \mathrm{dm}^{-3}\right)$. This initiated the clay flocculation process, and promoted soil aggregation improvements (Cremon et al., 2009; Ramos et al., 2013; Silva et al., 2013).

In G-0, although no additional gypsum was applied to supply Ca for plant nutrition, calcium nitrate (105 $\mathrm{kg} \mathrm{ha}^{-1}$ ) was used to maintain adequate to high soil $\mathrm{Ca}^{2+}$ levels (Ramos et al., 2013), explaining the very stable aggregates observed in this treatment.

In the conventional management (CV-0), in which the rows were maintained bare, with no cover crop, the only organic residue added to the soil came from the coffee crop, so there was no continuous supply of exchangeable $\mathrm{Ca}$ to the soil, which explains the lower aggregate stability of this treatment (Table 4). In summary, these results demonstrate that highly weathered Oxisols under coffee managed with an additional dose of gypsum and intercropping with Brachiaria favor soil aggregation, and consequently the physical properties.

It should be noted that while maximum aggregate stability using the HEMC method is reached with a SR value of 1 , in this study SR values were between 0.33 and 0.58 . The values found in this study were lower than those reported by Avanzi et al. (2011), between 0.59 and 0.85 , also using the HEMC technique, in different soils under eucalypt plantations and native forest in the 0-0.10 m layer. However, the area monitored by Avanzi et al. (2011) was under management for 7 years, whereas the area used in our study had been managed for only 2.5 years. Therefore, in the experimental area, beneficial results are expected over time, since a layer of gypsum was undissolved at an approximate depth of $0.15 \mathrm{~m}$, and possibly the effects of this agricultural input would eventually become noticeable, allowing for a greater differentiation of treatments.

Another objective of this study was to quantify the inter-aggregate porosity, and to this end, water retention curves (WRC) were adjusted using the van Genutchen model (Figure 3). The models adjusted adequately to the data, obtaining coefficients of determination $\left(\mathrm{R}^{2}\right)$ between 0.95 and 0.99 .

The different soil management systems under coffee altered the shape of the water retention curves (WRC) (Figure 3a,b,c,d). This phenomenon can be related to the variation in the OM content observed under the different managements (Silva et al., 2013) which, according to Araujo Junior et al. (2011), alters the shape parameters of the WRC ( $m$ and $n$ ) and, consequently, the pore-size distribution (Table 5).
Under slow wetting, the WRC behavior under CV0 was more differentiated, with visibly higher water contents at matric potentials between 0 and $-3 \mathrm{kPa}$ (Figure 3b,c,d). However, when analyzing the MS values (Table 4), which were related to this behavior, no statistical difference was observed. In the pore-size distribution analysis, however, the presence of a higher volume of pores with a diameter of less than $99 \mu \mathrm{m}$ was observed (Table 5). Possibly, this was associated with aggregate slaking, which is less resistant to this management system (Table 4), caused by rupturing during the HEMC analysis and contributed to greater wetting. Under the management treatments G0, G7, and G28, the aggregates were more stable and had more internal pores, as indicated by the pore-distribution by diameter (Table 5). This was mainly due to the presence of interrow Brachiaria that was regularly cut and the cuttings left in the coffee rows.

In slow-wetted aggregates no differences between managements were detected, due to similarities in the pore-diameter distribution (Table 5). Moreover, the WRCs obtained at this wetting rate (Figures $3 \mathrm{~b}$ and $3 \mathrm{~d}$ ), showed that a descending order of water retention under $\Psi-3 \mathrm{kPa}$ was established: $\mathrm{CV}-0>$ G-0 $>$ G-7 $>$ G-28, and this sequence corresponded to the behavior expressed by VDP (Table 4). It is important to emphasize that the slower the aggregate wetting speed, the lower were the impacts generated by occupation of the water in the spaces of the aggregates, and the pressure buildup within aggregates was lower, reducing the clay expansion rate and decreasing aggregate slaking (Lado et al., 2004).

In G-7, the pore-diameter distribution was more homogeneous (Figure 3), as indicated by the smooth slope of the curve; this may be related to the aggregate size distribution, and consequently the $\mathrm{C}$ storage capacity, which corroborates findings of Silva et al. (2013), who observed that under this management, aggregates were smaller than in the G-28 management.

Costa Júnior et al. (2012) found that smaller aggregates have a greater ability to absorb C. In this study, the correlation between SI for fast wetting and the soil exchangeable Ca content was positive $(\mathrm{r}=$ $0.73)$ and significant $(p<0.01)$. However, despite the fact that the $\mathrm{Ca}^{2+}$ ion promotes flocculation of the soil clay fraction, it is noteworthy that at high concentrations, $\mathrm{Ca}^{+2}$ can displace $\mathrm{Al}^{3+}$ from the clay surface (initial condition), which can trigger dispersion in the clay fraction (Serafim et al., 2012). This may have occurred in the high-gypsum treatment.

There are few studies that define the wetting rates of tropical soils, since it is not confirmed that the maximum slaking value of these soils occurs when subjected to a rate of $100 \mathrm{~mm} \mathrm{~h}^{-1}$. However, the results obtained so far confirm the potential use of this technology. 
Table 5. Pore-size distribution obtained by the fast/slow wetting methods at a depth of $0.05 \mathrm{~m}$ and of $0.20 \mathrm{~m}$ under different management systems

\begin{tabular}{|c|c|c|c|c|c|c|c|c|}
\hline \multirow{3}{*}{ Management } & \multicolumn{8}{|c|}{ Pore diameter $(\mu \mathrm{m}) * * * *$} \\
\hline & $>599$ & 599-299 & 299-199 & $<99$ & $>599$ & $599-299$ & 299-199 & $<99$ \\
\hline & \multicolumn{4}{|c|}{$0.05 \mathrm{~m}$} & \multicolumn{4}{|c|}{$0.20 \mathrm{~m}$} \\
\hline & \multicolumn{8}{|c|}{ Fast wetting $\left(\mathrm{g} \mathrm{g}^{-1}\right)$} \\
\hline CV -0 & $0.17 \mathrm{~A}$ & $0.05 \mathrm{~A}$ & $0.02 \mathrm{~A}$ & $0.38 \mathrm{~A}$ & $0.17 \mathrm{~B}$ & $0.06 \mathrm{~A}$ & $0.02 \mathrm{~A}$ & $0.49 \mathrm{~A}$ \\
\hline G-0 & $0.27 \mathrm{~A}$ & $0.08 \mathrm{~A}$ & $0.03 \mathrm{~A}$ & $0.23 \mathrm{~B}$ & $0.28 \mathrm{~A}$ & $0.08 \mathrm{~A}$ & $0.03 \mathrm{~A}$ & $0.33 \mathrm{~B}$ \\
\hline G-7 & $0.25 \mathrm{~A}$ & $0.08 \mathrm{~A}$ & $0.03 \mathrm{~A}$ & $0.24 \mathrm{~B}$ & $0.20 \mathrm{~B}$ & $0.07 \mathrm{~A}$ & $0.03 \mathrm{~A}$ & $0.29 \mathrm{~B}$ \\
\hline \multirow{2}{*}{ G-28 } & $0.31 \mathrm{~A}$ & $0.08 \mathrm{~A}$ & $0.03 \mathrm{~A}$ & $0.21 \mathrm{~B}$ & $0.21 \mathrm{~B}$ & $0.07 \mathrm{~A}$ & $0.03 \mathrm{~A}$ & $0.36 \mathrm{~B}$ \\
\hline & \multicolumn{8}{|c|}{ Slow wetting $\left(\mathrm{g} \mathrm{g}^{-1}\right)$} \\
\hline CV -0 & $0.16 \mathrm{~A}$ & $0.03 \mathrm{~A}$ & $0.01 \mathrm{~A}$ & $0.44 \mathrm{~A}$ & $0.24 \mathrm{~A}$ & $0.06 \mathrm{~A}$ & $0.02 \mathrm{~A}$ & $0.38 \mathrm{~A}$ \\
\hline G-0 & $0.21 \mathrm{~A}$ & $0.06 \mathrm{~A}$ & $0.02 \mathrm{~A}$ & $0.42 \mathrm{~A}$ & $0.26 \mathrm{~A}$ & $0.08 \mathrm{~A}$ & $0.03 \mathrm{~A}$ & $0.25 \mathrm{~A}$ \\
\hline G-7 & $0.19 \mathrm{~A}$ & $0.06 \mathrm{~A}$ & $0.02 \mathrm{~A}$ & $0.34 \mathrm{~A}$ & $0.23 \mathrm{~A}$ & $0.07 \mathrm{~A}$ & $0.03 \mathrm{~A}$ & $0.24 \mathrm{~A}$ \\
\hline $\mathrm{G}-28$ & $0.19 \mathrm{~A}$ & $0.06 \mathrm{~A}$ & $0.03 \mathrm{~A}$ & $0.32 \mathrm{~A}$ & $0.22 \mathrm{~A}$ & $0.06 \mathrm{~A}$ & $0.02 \mathrm{~A}$ & $0.30 \mathrm{~A}$ \\
\hline
\end{tabular}

Means followed by the same uppercase letter in the column do not differ by the Scott-Knott test at $5 \%$. ${ }^{* * *}$ : significant (p<0.001).
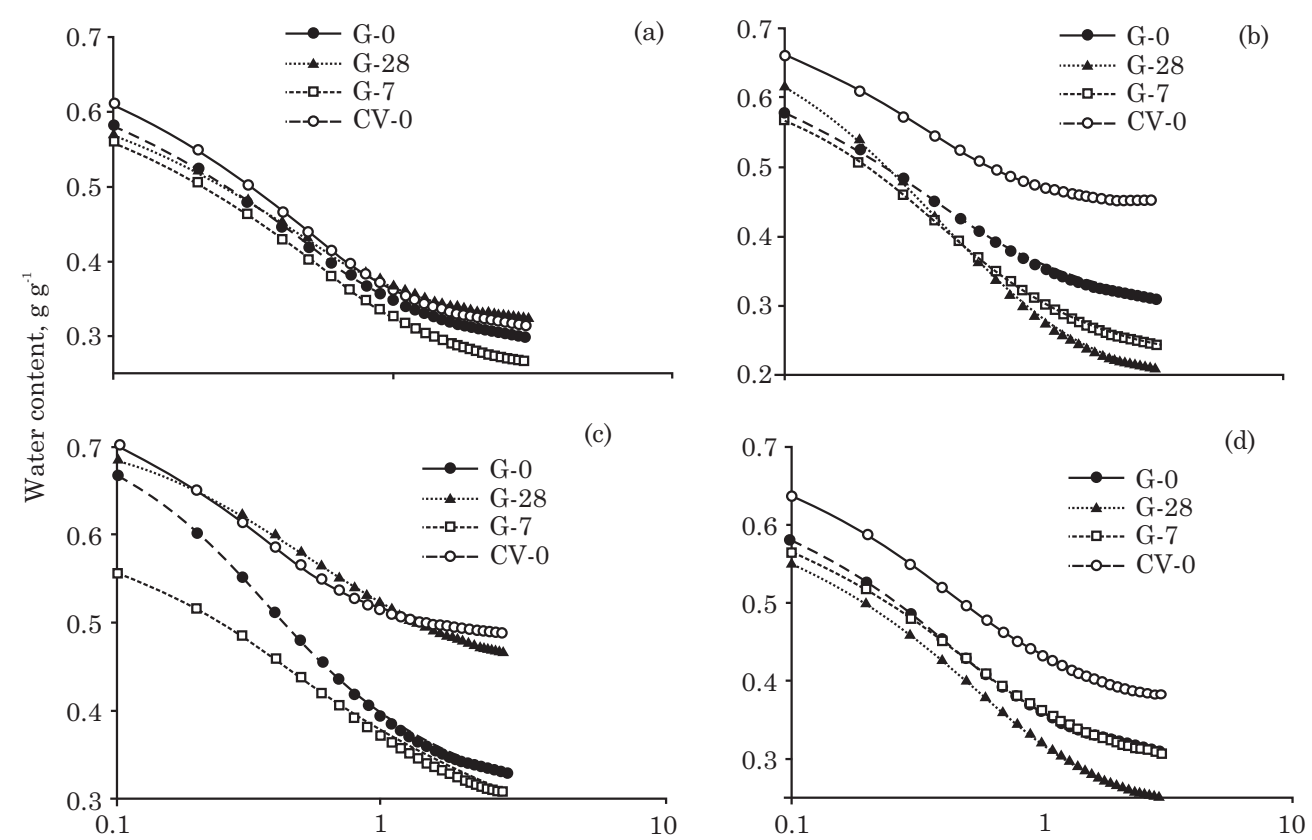

Matric potential, $\mathrm{kPa}$

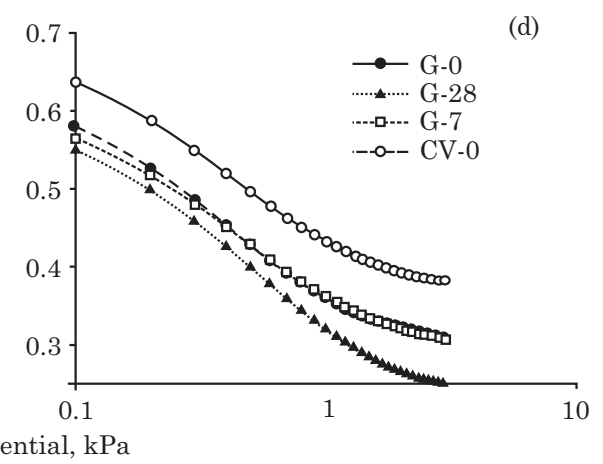

Figure 3. Water retention curves generated by the HEMC technique $(M=f(\Psi))$ : (a) fast wetting $(0.05 \mathrm{~m})$, (b) slow wetting $(0.05 \mathrm{~m})$, (c) fast wetting $(0.20 \mathrm{~m})$, and $(\mathrm{d})$ slow wetting $(0.20 \mathrm{~m})$.

\section{CONCLUSIONS}

1. Soil management under coffee with additional gypsum application and interrow Brachiaria cultivation resulted in a soil aggregate $\mathrm{SR}$ higher than that under conventional management, particularly at the highest agricultural gypsum dosage.

2. Soil under conventional management system had a large number of small pores $(<99 \mu \mathrm{m})$.

3. The High Energy Moisture Characteristic technique demonstrated that a reduction in Oxisol aggregate stability is related to a fast wetting rate $\left(100 \mathrm{~mm} \mathrm{~h}^{-1}\right)$.

\section{ACKNOWLEDGMENTS}

To CNPq for the granting of scholarships. To FAPEMIG for financial support, to the Consórcio de Pesquisas Cafeeiras Embrapa-Café for providing vehicles and the Empresa Agropecuária Piumhí (AP) in the person of Agronomy Engineer Alessandro 
Oliveira for logistical support and use authorization of the experimental area. To UFLA/DCS for institutional support to accomplish this work.

\section{LITERATURE CITED}

AVANZI, J.C.; NORTON, L.D.; SILVA, M.L.N.; CURI, N.; OLIVEIRA, A.H. \& SILVA, M.A. Aggregate stability in soils cultivated with eucalyptus. Pesq. Agropec. Bras., 46:89-96, 2011.

ARAUJO JÚNIOR, C.F.; DIAS JUNIOR, M.S.; GUIMARÃES, P.T.C. \& ALCÂNTARA, E.N. Capacidade de suporte de carga e umidade crítica de um Latossolo induzida por diferentes manejos. R. Bras. Ci. Solo, 35:115-131, 2011.

ASSOCIAÇÃO BRASILEIRA DE CAFÉS ESPECIAIS - BSCA. Lista de verificação de sistemas de gestão sócio-ambiental. Anexo RA 0552.04, ver. 01. 2005.

CASALINHO, H.D.; MARTINS, S.R.; SILVA, J.B. \& SILVA LOPES, A. Qualidade do solo como indicador de sustentabilidade de agroecossistemas. R. Bras. Agroci., 13:195-203, 2007.

COLLIS-GEORGE, N. \& FIGUEROA, B.S. The use of soil moisture characteristics to assess soil stability. Aust. J. Soil Res., 22:349-356, 1984.

COMISSÃO DE FERTILIDADE DO SOLO DO ESTADO DE MINAS GERAIS - CFSEMG. Recomendações para o uso de corretivos e fertilizantes em Minas Gerais. $5^{\text {a }}$ Aproximação. Viçosa, MG, 1999. 359p.

COSTA JÚNIOR, C.; PÍCCOLO, M.C.; SIQUEIRA NETO, M.; CAMARGO, P.B.; CERRI, C.C. \& BERNOUX, M. Carbono em agregados do solo sob vegetação nativa, pastagem e sistemas agrícolas no bioma cerrado. R. Bras. Ci. Solo, 36:1311-1321, 2012.

CHILDS, E.C. The use of soil moisture characteristics in soil studies. Soil Sci., 50:239-252, 1940.

CREMON, C.; ROSA JÚNIOR, E.J.; SERAFIM, M.E. \& ONO, F.B. Análise micromorfométrica de agregados de um Latossolo Vermelho distroférrico sob diferentes sistemas de manejo. Acta Sci., 31:139-146, 2009.

EMPRESA BRASILEIRA DE PESQUISA AGROPECUÁRIA - EMBRAPA. Centro Nacional de Pesquisas de Solos. Sistema brasileiro de classificação de solos. 2.ed. Rio de Janeiro, 2006. 306p.

FERREIRA, D.F. SISVAR: A computer statistical analysis system. Ci. Agrotec., 35:1039-1042, 2011.

FIALHO, C.M.T.; SILVA, A.A.; FARIA, A.T.; TORRES, L.G.; ROCHA, P.R.R. \& SANTOS, J.B. Teor foliar de nutrientes em plantas daninhas e de café cultivadas em competição. Planta Daninha, 30:65-73, 2012.

FIALHO, C.M.T.; FRANÇA, A.C.; TIRONI, S.P.; RONCHI, C.P. \& SILVA, A.A.D. Interferência de plantas daninhas sobre o crescimento inicial de Coffea arabica. Planta Daninha, 29:137-148, 2011.
KONDO, M.K.; ALBUQUERQUE, C.J.B.; WENDLING, B.; SILVA, P.B.D. \& CARDOSO, M.M. Efeito de coberturas vegetais sobre os atributos físicos do solo e características agronômicas do sorgo granífero. Biosci. J., 28:33-40, 2012.

LADO, M.; BENHUR, M. \& SHAINBERG, I. Soil wetting and texture effects on aggregate stability, seal formation, and erosion. Soil Sci. Soc. Am. J., 68:1992-1999, 2004.

LEVY, G.J. \& MAMEDOV, A.I. High energy moisture characteristic aggregate stability as a predictor for seal formation. Soil Sci. Soc. Am. J., 66:1603-1609, 2002.

LEVY, G.J. \& MILLER, W.P. Aggregate stabilities of some Southeastern U.S. soils. Soil Sci. Soc. Am. J., 61:1176$1182,1997$.

LIMA, V.M.P.; OLIVEIRA, G.C.; SERAFIM, M.E.; CURI, N. \& EVANGELISTA, A.R. Intervalo hídrico ótimo como indicador de melhoria da qualidade estrutural de Latossolo degradado. R. Bras. Ci. Solo, 36:71-78, 2012.

MAGALHÃES, E.N.; OLIVEIRA, G.C.; SEVERIANO, E.C.; COSTA, K.A.P. \& CASTRO, M.B. Recuperação estrutural e produção de capim-tifton 85 em um Argissolo VermelhoAmarelo compactado. Ci. Anim. Bras., 10:68-76, 2009.

MAMEDOV, A.I.; BECKMANN, S.; HUANG, C. \& LEVY, G.J. Aggregate stability as affected by polyacrylamide molecular weight, soil texture, and water quality. Soil Sci. Soc. Am. J., 71:1909-1918, 2007.

MINAS GERAIS. Certifica Minas café - regulamento geral. $8^{a}$ revisão. Belo Horizonte, 11/12/2009. Available: <http:// intranet.ima.mg.gov.br/nova/gec/outros_documentos/ Cafe/Regulamento\%20certificaminascafe-versao8.pdf $>$. Accessed: Set. 9, 2013.

MUALEM, Y. A new model for predicting the hydraulic conductivity of unsaturated porous media. Water Resour. Res., 12:513-522, 1976.

PIERSON, F.B. \& MULLA, D.J. An improved method for measuring aggregate stability of a weakly aggregated loessial soil. Soil Sci. Soc. Am. J., 53:1825-1831, 1989.

RAMOS, B.Z.; TOLEDO, J.P.V.F.; LIMA, J.M.; SERAFIM, M.E.; BASTOS, A.R.; GUIMARÃES, P.T.G. \& COSCIONE, A.R. Doses de gesso em cafeeiro: Influência nos teores de cálcio, magnésio, potássio e pH na solução de um Latossolo Vermelho distrófico. R. Bras. Ci. Solo, 37:1018-1026, 2013.

RIBEIRO, B.T.; LIMA, J.M.; MELLO, C.R.; SÁ, M.A.C. \& OLIVEIRA, G.O. Relationship between raindrops and ultrasonic energy on the disruption of a Haplic Cambisol. Ci. Agrotec., 33:814-823, 2009

SÁ, M.A.C.; LIMA, J.M.; SILVA, M.L.N. \& DIAS JUNIOR, M.S. Comparação entre métodos para o estudo da estabilidade de agregados em solos. Pesq. Agropec. Bras., 35:1825-1834, 2000.

SEKI, K. Swrc fit - A nonlinear fitting program with a water retention curve for soils having unimodal and bimodal pore structure. Hydrol. Earth Syst. Sci. 4:407-437, 2007.

SERAFIM, M.E.; OLIVEIRA, G.C.; OLIVEIRA, A.S.; LIMA, J.M.; GUIMARÃES, P.T.G. \& COSTA, J.C. Sistema conservacionista e de manejo intensivo do solo no cultivo de cafeeiros na região do alto São Francisco, MG: Um estudo de caso. Biosci. J., 27:964-977, 2011. 
SERAFIM, M.E.; DE LIMA, J.M.; LIMA, V.M.P.; ZEVIANI, W.M. \& PESSONI, P.T. Alterações físico-químicas e movimentação de íons em Latossolo gibbsítico sob doses de gesso. Bragantia, 71:75-81, 2012.

SERAFIM, M.E.; OLIVEIRA, G.C.; LIMA, J.M.; SILVA, B.M.; ZEVIANI, W.M. \& LIMA, V.M.P. Disponibilidade hídrica e distinção de ambientes para cultivo de cafeeiros. R. Bras. Eng. Agríc. Amb., 17:362-370, 2013.

SEVERIANO, E.C.; OLIVEIRA, G.C.; DIAS JUNIOR, M.S.; COSTA, K.A.P.; CASTRO, M.B. \& MAGALHÃES, E.N. Potencial de descompactação de um Argissolo promovido pelo capim-tifton 85. R. Bras. Eng. Agríc. Amb., 14:39-45, 2010.

SILVA, B.M.; OLIVEIRA, G.C.; SILVA, E.A.; OLIVEIRA, L.M. \& SERAFIM, M.E. Índice $\mathrm{S}$ no diagnóstico da qualidade estrutural de Latossolo muito argiloso sob manejo intensivo. Biosci. J., 28:338-345, 2012.
SILVA, E.A.; OLIVEIRA, G.C.; CARDUCCI, C.E.; SILVA, B.M.; OLIVEIRA, L.M. \& COSTA, J.C. Increasing doses of agricultural gypsum, aggregate stability and organic carbon in Cerrado Latosol under coffee crop. R. Ci. Agrár., 56:25-32, 2013.

SIX, J.; OGLE, S.M.; BREIDT, F.J.; CONANT, R.T.; MOSIER, A.R. \& PAUSTIAN, K. The potential to mitigate global warming with no-tillage management is only realized when practiced in the long term. Global Change Biol., 10:155-160, 2004.

van GENUCHTEN, M.T. A closed-form equation for predicting the hydraulic conductivity of unsaturated soils and water quality. Soil Sci. Soc. Am. J., 44:892-898, 1980.

YODER, R.E. A direct method of aggregate analysis of soils and a study of the physical nature of erosion losses. J. Am. Soc. Agric., 28:337-351, 1936. 